\title{
Significant Role of Economic Growth in Alleviating Poverty
}

\author{
$1^{\text {st }}$ Syaeful Bakhri \\ Faculty of Shariah and Islamic \\ Economics \\ IAIN Syekh Nurjati \\ Cirebon, Indonesia \\ sultan01aulia@yahoo.com
}

\author{
$2^{\text {nd }}$ Bambang \\ Faculty of Economics and Business \\ Jenderal Soedirman University \\ Indonesia
}

\author{
$3^{\text {rd }}$ Pahrul Fauzi \\ Faculty of Economics and Business \\ University of Wijayakusuma \\ Indonesia
}

\begin{abstract}
The problem of poverty is related to various regional conditions, not only in rural areas but also in urban areas. Poverty in urban areas has its own characteristics with various factors that influence it. This study aims to determine the role of economic growth, inflation, and population growth on poverty level. This was a quantitative study with path analysis and multiple regression analysis. The results of the study evidenced that economic growth had a significant effect on poverty level with a value ( $t_{\text {count }}$ of 2.896). Inflation ( $t_{\text {count }}$ of $\mathbf{0 . 0 9 6}$ ) and population growth ( $t_{\text {countof }} 0.726$ ) had bo significant effect on poverty levels. Open unemployment rate variable ( $\left.t_{\text {countof }} 1.721\right)$ and human development index ( $t_{\text {countof }}$ 1.255) also had no significant effect on poverty level. Based on these findings, efforts to allevite poverty level need to be pursued continuously by optimizing macroeconomic variables such as the rate of economic growth and controlling the inflation rate.
\end{abstract}

Keywords-Economics, Alleviating, Poverty

\section{INTRODUCTION}

The development performance of a country can be measured by several key indicators such as economic growth, inflation, unemployment rates, HDI, percentage of poor people, and so on. Economic growth can be said to be of quality if it is able to have a positive impact on various development indicators.[1]One problem that is often become the goal of development is poverty alleviation.[2]Poverty is a social problem that is interrelated with many factors that influence it.Indonesia as a developing country continues to make efforts to alleviate the problem of poverty, which is heavily influenced by the socio-economic dimension, not least in Indonesia.[3]In general, poverty criteria in Indonesia can be mapped territorially, namely poverty in urban and rural area.[4]Poverty in urban areas is concentrated in big cities in Indonesia, with characteristics that are close to slums and dense settlements.[5]

As one of the metropolitan cities in West Java Province, Cirebon City also experiences such poverty. The approach in understanding and solving poverty problems in urban areas, including in Cirebon City, is different from understanding poverty problems in rural areas.[2] The influence of education, asset ownership, and access to health facilities factors are the main problems that exacerbate the problem of poverty in urban areas.[6][7]Based on this, this study seeks to determine the effect of macro development indicator variables on poverty level.

\section{STUDY METHODS}

This study used a quantitative approach thorugh secondary data. The variables of this study were Economic Growth (EG), Inflation (INF), and Population Growth (PG) as independent variables, which were analyzed for their effects on the Poverty Level (PL) through Open Unemployment Rate (OUR) variable and Human Development Index (HDI) in Cirebon City. To find out the effect of several variables that were studied on the level of poverty, multiple regression analysis with path analysis was performed. Path Analysis is a complementary methodology of regression analysis that can display a causal relationship.[8] 


\section{RESULTS}

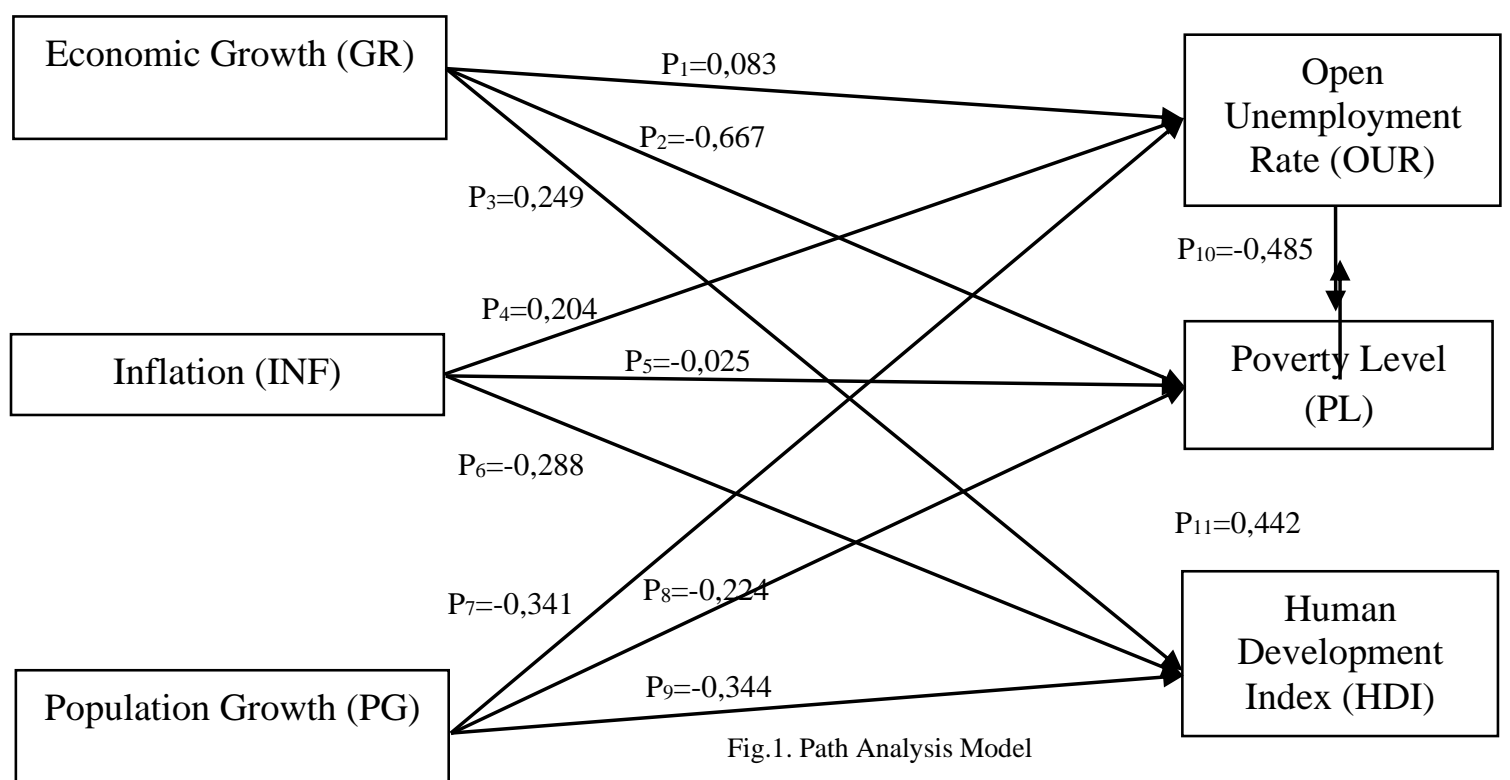

Based on Figure 1, three structural equations can be formulated as follows:

$\mathrm{TKt}=-0,667 \mathrm{PEt}-0,025 \mathrm{INFt}-0,224 \mathrm{PPt}-0,485 \mathrm{TPTt}+0,442 \mathrm{IPMt}$

$\mathrm{TPTt}=0,083 \mathrm{PEt}+0,024 \mathrm{INFt}-0,341 \mathrm{PPt}$

$\mathrm{IPMt}=0,249 \mathrm{PEt}-0,288 \mathrm{INFt}-0,344 \mathrm{PPt}$

The result of regression calculation with path analysis will display the results of hypothesis testing, which can be seen in Table I. below.

TABLE I. SUMMARY OF HYPOTHESIS TESTING

\begin{tabular}{|c|c|c|c|c|c|c|}
\hline \multirow[t]{2}{*}{ Exogenous Variable } & \multicolumn{2}{|c|}{$\mathrm{PL}$} & \multicolumn{2}{|c|}{ OUR } & \multicolumn{2}{|c|}{ HDI } \\
\hline & Coefficient & $\mathrm{T}_{\text {count }}$ & Coefficient & $\mathrm{T}_{\text {count }}$ & Coefficient & $\mathrm{T}_{\text {count }}$ \\
\hline PL & -0.667 & $-2.896 *$ & 0.083 & 0.237 & 0.249 & 0.881 \\
\hline EG & -0.224 & -0.726 & -0.341 & -0.832 & -0.344 & -1.041 \\
\hline OUR & 0.485 & 1.721 & & & & \\
\hline HDI & 0.422 & 1.255 & & & & \\
\hline
\end{tabular}

Information: $*$ significant at $\alpha=5 \% \mathrm{n}=14, \mathrm{t}_{\text {table }}=2.160$

Based on Table I. it can be concluded that several study findings related to hypothesis testing were as follows:

a. Economic Growth (EG) Variable had a significant effect on PL, but had no significant

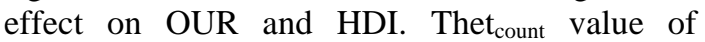
Economic Growth (EG) variable towards the Poverty Level (PL) was |-2.896| or higher than the $t_{\text {tablevalue of }}(2.160)$, while the $t_{\text {count }}$ values ofOUR and HDI variables were 0.237 and 0.881 , respectively or lower than thet table value of (2.160).

b. Inflation (INF) variable had no significant effect on PL, Open Unemployment Rate (OUR), and HDI where the $t_{\text {count }}$ value of inflation variable towards the three endogenous variables were 0.096|, $|0.483|$ and $|-0.846|$ or lower than $\mathrm{t}_{\text {table }}$ of (2.160). c. Population Growth (PG) variable had no significant effect either on Poverty Level (PL), Open Unemployment Rate (OUR) and on Human Development Index (HDI). $t_{\text {count }}$ values of $\mid$ 0.726|, |-0.832| and |-1,041| were lower than the

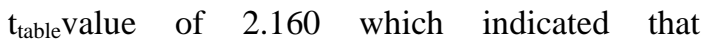
Population Growth (PG) variable had no significant effect onPL, OUR, or HDI.

d. The Open Unemployment Rate variable had no significant effect on PL. With a $t_{\text {countvalue of }}$ 1.721 or lower than thet table of 2.160 , it can be concluded that OUR had no significant effect on Poverty Level (PL).

e. HDI variable showed a $t_{\text {count }}$ of 1.255 or lower than the $t_{\text {table }}$ of 2.160. This indicated that HDI variable had no significant effect on Poverty Level(PL). 
TABLE II. SOBEL TEST RESULTS

\begin{tabular}{|l|c|c|c|c|c|}
\hline \multirow{2}{*}{$\begin{array}{l}\text { Exogenous } \\
\text { Variable }\end{array}$} & \multicolumn{2}{|c|}{$\begin{array}{c}\text { Indirect Effect Coefficient } \\
\text { Through: }\end{array}$} & \multicolumn{2}{|c|}{$\mathrm{T}_{\text {count }}$} & \multicolumn{1}{c}{ Conclusion } \\
\cline { 2 - 5 } & OUR & HDI & OUR & HDI & \\
\hline EG & 0.0402 & -0.1050 & 0,5433 & 1,508 & OUR and HDI were not intervening variables \\
\hline INF & 0.0116 & $-0,1215$ & 18,675 & $-19,751$ & OUR and HDI wereintervening variables \\
\hline PG & -0.1653 & $-0,1451$ & $-2,043$ & $-1,966$ & OUR and HDI were not intervening variables \\
\hline
\end{tabular}

Information: table $=2.201(\mathrm{n}=14 ; \mathrm{k}=3 ; \alpha=5 \%)$

I Based on Table II. it can be explained thatOpen Unemployment Rate (OUR) and HDI were not variables that influenced Economic Growth. However, OUR and HDI became variables that influenced the inflation level. The same table also explained that OUR and HDI had no effect on Population Growth (PG).

\section{DISCUSSION}

\section{A. Effect of Economic Growth on Poverty Level}

Table I showed that Economic Growth (EG) variable had asignificant effect onPoverty Level (PL) variable. However, Table 2 showed that OUR and HDI variables were not intervening variables for the Economic Growth (EG) variable towardsPL. Therefore,Economic Growth (PE) variable only had a direct effect on Poverty Level (PL) and had no indirect effect on OUR and HDI.

Tambunan stated that economic growth without being followed by additional employment opportunities would create a condition of economic growth with increased poverty.[9]There was a very strong correlation between Economic Growth and Poverty Level. In the early stages of the development process, the poverty level has a tendency to increase and when entering the final stage of development, it will gradually decrease in accordance with the ongoing stages of development.

According to Siregar, economic growth is an indicator to see the success of development as well as being a parameter for reducing the poverty level. The adequacy requirement that economic growth is effective is its effect in alleviating poverty.[10]This explains that economic growth should spread to each income group, including the poor population. Directly, economic growth is certain to occur in the sectors where the poor people work, especially in the agricultural or labor-intensive sectors.[11]Indirectly, this means that quite effective government performance is needed in its role in distributing growth benefits such as capital-intensive services. This is also supported by a study conducted by Wongdesmiwati in Wahyudi and Rejekeningish found that there was a negative relationship between economic growth and poverty level. An increase in economic growth would decrease the level of poverty.[12]

\section{B. Effect of Inflation on Poverty Level}

In Table I it was explained that although inflation (INF) had no significant effect on PL, but in Table II it was explained that Inflation (INF) had an indirect effect on Poverty Level (PL) through OUR and HDI variables.

In Table II it was shown that the coefficient of positive indirect effect Inflation through OUR indicatedan increased inflation rate whoch in turn will cause the Open Unemployment Rate (OUR) to increaseso that the Poverty Levelwill also increase. The coefficient on the negative indirect effect of inflation through HDI indicated that an increased inflation rate would cause the HDI to decrease. Decrease in HDI will cause an increase in poverty level.

The result of this study is in line with a study conducted by Fatma which found that inflation through unemployment had a significant and direct effect on poverty level.[13]An increase in inflation and unemployment will resulted in an increase in the number of poor people. Cutler \& Katz and Powers found that inflation and unemployment rates had a positive effect on the population below the poverty line; the higher the inflation and unemployment rates, the greater the Poverty Level.[13]Furthermore, Hoover \& Wallace found that Poverty Level was very responsive to labor market conditions (unemployment and wage rates). As an indicator of the quality of human capital, HDI intervenes the effect of inflation on PLsince existing inflation will affect people'spurchasing power especially in meeting their basic needs (food, education, and health).[3]

\section{Effect of Population Growth on Poverty Level}

In contrast to the Economic Growth (EG) and Inflation (INF) variables, Population Growth (PG) variable had no effect on Poverty Level either directly or indirectly. This explained that the OUR and HDI variables were not intervening variables.

Population growth in the context of a region's economic development is a very fundamental problem, because the uncontrolled population growth can result in not achieving the objectives of economic development, namely the welfare of the people and poverty alleviation.[14]There was a direct effect of population growth that occurred in an area on the level of community welfare. The relatively rapid population growth in developing countries is one cause of the decline in the level of social welfare. In the long term this will be the cause of the decline in welfare and increase the number of poor people.[15]A study conducted by Adhi also showed that there was a positive correlation between population and poverty, so the more the population increased, the more the number of poor people.

Population Structure Population is also very important for economic growth. Meanwhile, age structure of the population is largely determined by the stage of a country in the demographic transition.[16]In simple logic, it can be explained that the more productive age population in a country, the more the country will experience a decrease in poverty. In contrast to previous study, Population Growth (PG) variable in this study had no effect on PL. Whether the relationship between population and poverty level can have influence or not can be seen from the aspect of the quality of population growth. Even some social and demographic researchers are still debating 
whether population growth in a country is generally able to increase economic growth or vice versa.[17]

Population growth has a positive impact when its growth can encourage economic development, meaning that an increase in the number of population can enable the addition of a workforce that is able to encourage the production sector to increase economic activity. Population growth can have a negative effect whensuch growth hampers the economic development, meaning that an increase in population cannot increase the production so as to reduce the need for consumption of production products. On the other hand, population growth has no effect on PL if the population growth has no significant impact on the economy. Population growth was evidencedas nothaving effect on poverty in this study. With its economic base in the secondary and tertiary sectors, Cirebon City needs educated and skilled residents. A high population growth is caused by population migration than the birthrate rate, where it is not guaranteed that new residents can contribute to the economy. The average population growth of the last 10 years, which was only $0.9 \%$, was also allegedly not in accordance with the needs of the economic sector.

\section{CONCLUSIONS}

Based on the results of the study it can be concluded as follows: 1). Economic Growth (EG) had a significant effect on PL, but had no significant effect on OUR and HDI; 2). Inflation (INF) had no significant effect on PL, Open Unemployment Rate (OUR), and HDI; 3). Population Growth (PG) had no significant effect either on Poverty Level (PL), Open Unemployment Rate (OUR)and Human Development Index (HDI); 4). Open Unemployment Rate (OUR) had no significant effect on Poverty Level (PL); and 5). HDI had no significant effect on Poverty Level (PL).

\section{REFFERENCES}

[1] D. S. Jayadi and A. G. Bata, "Peran Pertumbunan Ekonomi Dalam Menurunkan Kemiskinan Di Tingkat Provinsi Di Indonesia MODUS Vol. 28 (1), 2016 Tahun 2004-2012," MODUS, vol. Vol.28 (1), pp. 87-99, 2016.

[2] S. P. Marmujiono, "Analisis Faktor-Faktor yang Mempengaruhi Tingkat Kemiskinan dan Strategi Pengentasan Kemiskinan di Kab. Brebes Tahun 2009-2011," Econ. Dev. Anal. J., vol. EDAJ 3 (1), pp. 159-172, 2014.

[3] S. S. Ningrum, "Analisis Pengaruh Tingkat Pengangguran Terbuka, Indeks Pembangunan Manusia, Dan Upah Minimum Terhadap Jumlah Penduduk Miskin Di Indonesia Tahun 20112015," J. Ekon. Pembang., vol. 15, no. 2, p. 184, 2017.

[4] M. Puspitasari, V. Nurmalasari, and A. Sjafii, "Investigating Economic Growth Impact on Poverty Reduction in East Java : Does Spatial Matter?,” Maj. Ekon., no. 1, pp. 1-12, 2011.

[5] P. Yandri and B. Juanda, "Memahami karakter kemiskinan perkotaan dengan pendekatan observasional," J. Ekon. dan Stud. Pembang., vol. 19, no. 1, pp. 75-84, 2018.

[6] B. D. Sanjaya and S. A. Kadir, "Analisis Kemiskinan di Kota Pagar Alam," J. Ekon. Pembangunan, Univ. Sriwij., vol. 16, no. 2, pp. 81-93, 2018.

[7] R. R. Ramadhan and Y. Setiadi, "Pengaruh Modal Fisik dan Sumber Daya Manusia terhadap Indeks Inklusif di Indonesia," J. Ekon. Pembang., vol. 17, no. December, pp. 109-124, 2019.

[8] J. Ahn, "Beyond single equation regression analysis: Path analysis and multi-stage regression analysis," Am. J. Pharm. Educ., vol. 66, no. 1, pp. 37-42, 2002.

[9] I. Nuraini and H. F. Hariyani, "Quality Economic Growth as an
Indicator of Economic Development," J. Ekon. Pembang. Kaji. Masal. Ekon. dan Pembang., vol. 20, no. 1, pp. 80-86, 2019.

[10] M. K. Raoul, "Inequality in the Access to Social Housing in Cameroon: A Decomposition of the Poverty Effect," J. Ekon. dan Stud. Pembang., vol. 10, no. 1, pp. 14-24, 2018.

[11] M. A. Arham, A. Fadhli, S. I. Dai, U. N. Gorontalo, and U. N. Gorontalo, "Does Agricultural Performance Contribute to Rural Poverty Reduction in Indonesia?," JEJAK (Journal Econ. Policy) Unnes, vol. 13, no. 1, pp. 69-83, 2020.

[12] D. Wahyudi and T. W. Rejekingsih, "Analisis Kemiskinan Di Jawa Tengah," D J. Econ., vol. Volume 2, pp. 1-15, 2013.

[13] N. R. Primandari, "Pengaruh pertumbuhan ekonomi, inflasi dan pengangguran terhadap tingkat kemiskinan di Sumatera Selatan," J. Ekon. Pembang., vol. 16, no. 1, pp. 1-10, 2018.

[14] M. Irwan and J. P. Moeis, "Transmisi Kemiskinan Antargenerasi di Indonesia Tahun 1993 - 2014 , Studi Data IFLS Intergenerational Transmission of Poverty in Indonesia , 1993 - 2014 , Using IFLS Data Pendahuluan," J. Ekon. dan Pembang. Indones., vol. 19, no. 2, pp. 209-223, 2019.

[15] B. Sumargo, N. Miduk, and M. Simanjuntak, "Deprivasi Utama Kemiskinan Multidimensi Antarprovinsi di Indonesia Main Deprivation of Multidimensional Poverty among Provinces in Indonesia Pendahuluan," J. Ekon. dan Pembang. Indones., vol. 19, no. 2, pp. 160-172, 2019.

[16] S. Klasen and D. Lawson, "The impact of population growth on economic growth and poverty reduction in Uganda," econstor Make Your Publ. Visible., pp. 1-21, 2007.

[17] S. W. Sinding, "Population, poverty and economic development," Philos. Trans. R. Soc. B Biol. Sci., vol. 364, no. 1532 , pp. 3023-3030, 2009 